\title{
EVALUATION OF THE MANAGEMENT OF THE LAURENTIAN GREAT LAKES: THE ROLE OF US CONGRESSIONAL POLICYMAKING
}

\author{
KELLY TZOUMIS \& KATHLEEN WRUK \\ DePaul University, United States
}

\begin{abstract}
This research examines the importance of tone and issue framing by the United States Congress, using the case of the Laurentian Great Lakes (Great Lakes) from 2000 to 2019. Researching the tone of United States congressional committees, subcommittees and their witnesses, it is determined that congressional committees conduct hearings reflecting their public policy tone instead of more open discussions of the policy issues confronting the Great Lakes today. There is a statistically significant weak to moderate relationship of the tone of the committee, reflecting the same tone as the hearing. Similar to the tone of the committees mimicking the tone of the hearings, it appears that the tone of the witness reflects the tone of the hearing being conducted by the congressional committee. There is a statistically moderate to strong relationship between the tone of the witness and the tone of the hearing they attend. This is especially true for hearings conducted with an environmental protection tone and, to a lesser extent, with the tone of hearings and witnesses focused on commerce, industry and transportation. The research results lead to concerns regarding the fragmentation of Great Lakes public policymaking and the inability to address concerns for the Great Lakes, such as climate change, pollution and invasive species. Keywords: Great Lakes, congressional policymaking, public policy, issue definitions.
\end{abstract}

\section{INTRODUCTION}

The five Laurentian Great Lakes in North America (referred to as the Great Lakes) were formed during the Wisconsin glaciation period as recently as approximately 14,000 years ago. The lakes include Lake Superior, Lake Michigan, Lake Huron, Lake Erie, and Lake Ontario. These lakes, with the exception of Lake Michigan, form an aquatic border between eastern United States and Canada. Eight states have borders adjacent to the lakes: Illinois, Indiana, Michigan, Minnesota, New York, Ohio, Pennsylvania and Wisconsin, as well as the Canadian provinces of Ontario and Quebec. The Great Lakes basin constitutes a population of more than 30 million people which includes approximately $10 \%$ of the population in the United States and more than $30 \%$ of the Canadian population. These lakes represent close to a fifth of the planet's and $84 \%$ of North America's supply of fresh surface water [1]. The lakes directly generate more than 1.5 million jobs and $\$ 60$ billion in wages annually and include habitats for more than 3,500 plant and animal species, some of which are found nowhere else on Earth [2]. The region collectively forms a $\$ 4.7$ trillion economy, which is ranked as the fourth largest in the world [3]. The lakes have gone through significant degradation and restoration over the years related to commercial, industrial, agricultural, recreational, and transportation uses. Canada and the United States began international management of the lakes with the 1909 Boundary Waters Treaty. Management of the Great Lakes has evolved over time into a sophisticated and complex regime of institutions with numerous government agencies, commissions, and policies outlined in treaties and government regulations to both protect and utilize the ecosystem.

There are three branches of the United States federal government: the executive branch comprised of the President and federal bureaucracy; the legislative branch reflected in the United States Congress; and the judicial branch that includes the Supreme Court and a series 
of other federal courts. The United States constitution imposes a variety of checks and balances to limit each branch of government's influence, creating a co-equal tripartite balance while maintaining some distinction of duties and roles. The Congress is charged with crafting legislation, which is critical in the issue definition process for the Great lakes. Both chambers of Congress, the House of Representatives and the Senate, must agree on any piece of legislation, including all federal program funding, in order for the legislative bill to be passed onto the President; who signs the bill into law. This research examines the Congressional role in managing the Great Lakes, specifically examining the role of congressional hearings, which operate through congressional committees, and the witnesses who testify on the Great Lakes. It especially pays attention to the linkages of tone between the committees and witnesses in congressional hearings over time regarding the lakes. Because the lakes are such a significant natural resource, it is critical to understand the role of the United States congressional participants in framing the policy solutions surrounding this ecosystem.

\section{LITERATURE REVIEW}

Congress has a significant role in shaping the health of the Great Lakes in terms of policymaking. In the United States, congressional committees establish jurisdictional boundaries for policy issues, while committee hearings define and frame issues. Policy boundaries established by committees in congress need jurisdictional reinforcement to maintain continuity and distinction from other committees who may be looking to expand their policy jurisdiction [4]. As a result research on congressional public policy making is useful in understanding how issues concerning the Great Lakes are created and change over time. Research shows that a committee seeking to expand its scope of influence can use hearings to encroach on the jurisdictional boundaries of another committee [5]. Over time, committees can have a monopoly over certain issues which then can be challenged by other committees. In some policy domains like smoking, wetlands, and nuclear energy an erosion of issue dominance by the committee's monopoly of the policy jurisdiction can occur [6]. In these cases, research studies have shown that new committees and witnesses serve to redefine the policy and the committees staked out jurisdiction; this has been referred to as "turf wars" that take place in congressional policymaking among committees [5].

The role of congressional committees and their hearings, along with the role of issue definitions forming the basis of policymaking for the Great Lakes over time has been studied. Policy regarding the use and management of the lakes has been characterized as occurring in three distinct eras of time [7]. These eras each reflect dominance of a certain tone in congressional committees, hearings, and testifying witnesses. Tone is used in policy research to understand the propensity or tendency of how an issue is framed. The influence of these committees and witnesses help to define the issues and policies that are addressed in the Great Lakes ecosystem. The policy issues have been defined and re-defined over time, reflecting the priorities for the lakes during that particular time frame. The use of symbols, rhetoric, and congressional hearings reflect how these lakes are defined and managed over time. When policy change occurs in Congress, the tone is reflected in the committees and witnesses who participate in congressional hearings.

Era I of congressional policymaking on the lakes occurs from 1789-1965 with a dominant tone focusing on navigation, commerce, agriculture, and transportation. In 1966, issue definitions shift; focusing on environmental protection and human health [7]. By 1984, Era III ushers in what has been coined as an "agenda-sharing" time period reflective of a bounded issue model rather than one of dominance of a particular tone of public policymaking as was witnessed in Eras I and II. The three eras of congressional policymaking on the Great Lakes are: 
- Era I Navigation, Industry, and Commerce Dominance (1789-1965)

- $\quad$ Era II Shift to Environment and Health Dominance (1966-1983)

- $\quad$ Era III Agenda Sharing (1984-1999)

There are several non-congressional actors involved in the Great Lakes policy arena. The Clean Water Act charges the U.S. Environmental Protection Agency (EPA) with leading the effort to meet the requirements of the Great Lakes Water Quality Agreement. The act also statutorily established the Great Lakes National Program Office within EPA, charging it with, among other things, cooperating with federal, state, tribal, and international agencies to develop and implement specific action plans to carry out responsibilities under the agreement. In addition to the various governmental agencies involved in Great Lakes, several nongovernmental organizations have established environmental protection goals [8].

\subsection{Congressional policymaking on the Great Lakes}

Early in the history of the United States, the lakes were defined as being a navigation venue for commerce and population migration or transit to the Midwestern region of the country. The lakes were used by explorers, and later industrial entrepreneurs for their natural resources such as beaver fur, timber, and metals. The tone of the hearings, committees and witnesses focused on these types of issue definitions for the lakes. By the mid-1960s, the modern environmental movement in the United States shifted the issue definitions of the lakes to concerns about environmental protection and human health. This shift is reflected in the tone of the committees and hearings transitioning to concerns about pollution and contamination of the lakes versus their development for navigation for commerce and industry. A third transition occurs by 1984, when a bounded issue model evolves from the two previous eras. In Era III the previous tones of Eras I and II share the agenda in Congress. Rather than the dominance of a single-issue monopoly, multiple sets of many issues are reflected in policy making. This can be explained by the need to provide a sustainable use and development approach where one use does not create a negative impact on the environment or other users' needs for the lakes. This type of issue definition allows multiple definitions of how the lakes are managed and valued for the purpose of mutual coexistence. This is important because a negative impact by one user of the lakes can have devastating impacts on another. For instance, industrial uses of the lakes can negatively impact recreational, agricultural or public health sectors. Under this bounded issue model, congressional committees and their subcommittees handle differing aspects of the lakes simultaneously through different hearings without a dominating tone of influence. As a result, more than one issue definition of the lakes is portrayed in the hearings and witnesses.

\subsection{Era IV improving the management of the Great Lakes (2000-2019)}

This research examines the time period from 2000 to mid-2019 (Era IV) to determine if Great Lakes policymaking in the United States has evolved into a new or altered issue definition from the agenda-sharing reflective of the bounded issue model. Research questions explored include the definition of Great Lakes policymaking in congressional hearings, committees, and witnesses over the past 20 years.

A few of the major issues discussed in congressional hearings during this era include:

- 2002 Great Lakes Legacy Act

- 2004 Great Lakes Regional Collaboration

- 2008 Great Lakes Compact 
- 2010 Great Lakes Restoration Initiative

- 2012 Great Lakes Water Quality Agreement

The beginning of Era III creates a more sophisticated and complex foundation for managing the lakes, building on the policy work in Era II. It creates a variety of initiatives to address the human health and environmental protection of the lakes from a diversity of pollutants of the past. This work has continued to be refined in Era IV with an increased push from Congress on the EPA and other implementing agencies to focus on better methods and management to integrate across the fragmented policymaking system for the lakes. For instance, since 2000, the Government Accountability Office (GAO), an investigation arm of Congress, strongly recommends improvement for the continued management of the lakes [9], [10]. Some of the pollutants, known as bio-accumulative chemicals of concern (BCC), pose risks to humans and wildlife that consume them by remaining in the ecosystem. During Era I, the GAO recommended that the methods and standards for many of these BCC's (like mercury) be improved and better monitored during this period [9], [10]. Under the Great Lakes Legacy Act of 2002, 19 sites have been remediated.

The Great Lakes Restoration Initiative (GLRI) established in 2010 had as its foundation the 2004 Great Lakes Regional Collaboration. The goal of the 2010 initiative was to accelerate progress by targeting and prioritizing the largest threats to the lakes. This did not create new policies for the lakes but focused on accelerating work to complete already established areas of concern such as remediation of contaminated sites around the lakes, additional protection from invasive species, and nonpoint source pollution impacts to nearshore human health [11]. The GLRI is the largest investment in the Great Lakes in two decades and funds a variety of activities including grants and the direct implementation of Great Lakes Legacy Act projects [12]. The third Action Plan under the Great Lakes Restoration Initiative is expected in draft form in by the end of 2019. The plan will outline priorities and goals for the GLRI for the years 2020-2024. However, the theme of the last 20 years of Great Lakes policymaking appears to be one of not necessarily new and bold initiatives for the lakes but improving the management of the programs in place.

In 1972, Canada and the United states signed the Great Lakes Water Quality Agreement. It was amended in 1983 and again in 1987. During Era IV, the agreement was updated in 2012 to enhance water quality programs that ensure the chemical, physical, and biological integrity of the Great Lakes [13]. Another major cooperative arrangement within the United States occurred in 2008, when the Great Lakes Compact was approved by the legislatures of the eight Great Lakes states and by Congress. Under the Compact, eight Great Lakes states agree to adopt water-conservation plans and to abide by Compact rules for allowing and managing diversions of Great Lakes water. The Compact recognizes the lakes as a shared resource where no single state owns the lakes, but all states are stewards of this shared resource. As such, a defining feature of the Compact is its emphasis on using regional cooperation to manage the lakes as a single ecosystem [14].

At the close of the first decade of the $21^{\text {st }}$ century, the International Joint Commission which is a binational organization that coordinates Great Lakes issues across Canada and the United States provided overview reports on the lakes. It concluded that significant challenges continue in the management of the lakes. This includes the increase in harmful algal blooms in Lake Erie, the slow pace in addressing chemicals of mutual concern, and the spread of previously introduced invasive species. The Commission emphasizes that governments also need to pay additional attention to infrastructure investments that are essential to reduce risks to human health. It specifically states that that the water quality of western and central Lake Erie remains unacceptable [15]. 
Era IV does not reflect new challenges for the management of the lakes, but rather continued challenges that have not yet been resolved through governmental programs. The GAO reported that restoration efforts for the Great Lakes lacked leadership and organization and required a comprehensive strategy similar to ecosystem restoration projects in South Florida and the Chesapeake Bay of the United States which tended to be more effective [16]. This research examines if there has been a change in tone in Congress that may have resulted in a change in policy focus on the lakes to address these concerns and challenges and also establish a direction for future policy making by Congress.

\section{RESEARCH DESIGN AND METHODS}

\subsection{Sample description of Era IV improvement of managing the Great Lakes}

This research examines the current era of Great Lakes policymaking which begins immediately after the conclusion of Era III, January 2000. The research concludes with the most recent available data as of August 2019. Using the ProQuest Congressional Publication database, a keyword search was performed to identify congressional hearings concerning the Great Lakes conducted between 2000 and August 2019 [17]. An examination of all hearings for relevancy yielded a final dataset of 147 congressional committee and subcommittee hearings dealing directly with Laurentian Great Lakes policies. The dataset was hand coded to systematically analyze and evaluate the tone of the hearings, committees, subcommittees and witnesses testifying at these hearings. After nonparametric statistical testing, policy making eras were compared to examine changes in policy making.

The dataset includes a total of 20 committees, 31 subcommittees, and 442 witnesses. The number of hearings (Fig. 1) and witnesses per year (Fig. 2) illustrate the sample used in this analysis over time.

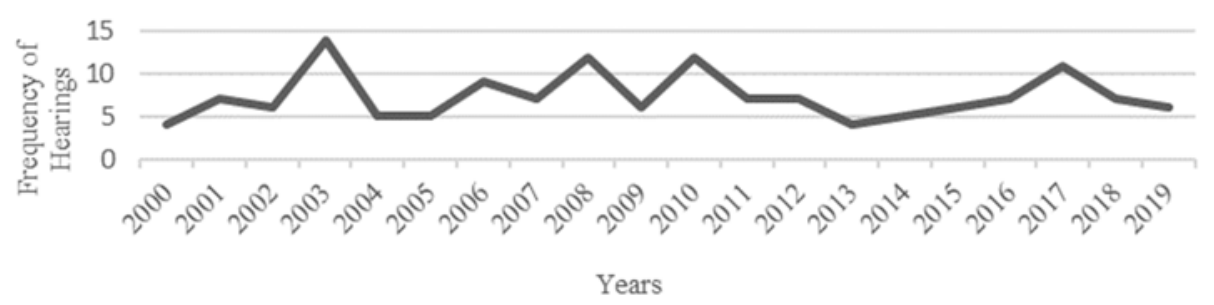

Figure 1: Congressional Hearings on the US Great Lakes 2000-2019 (n=147).

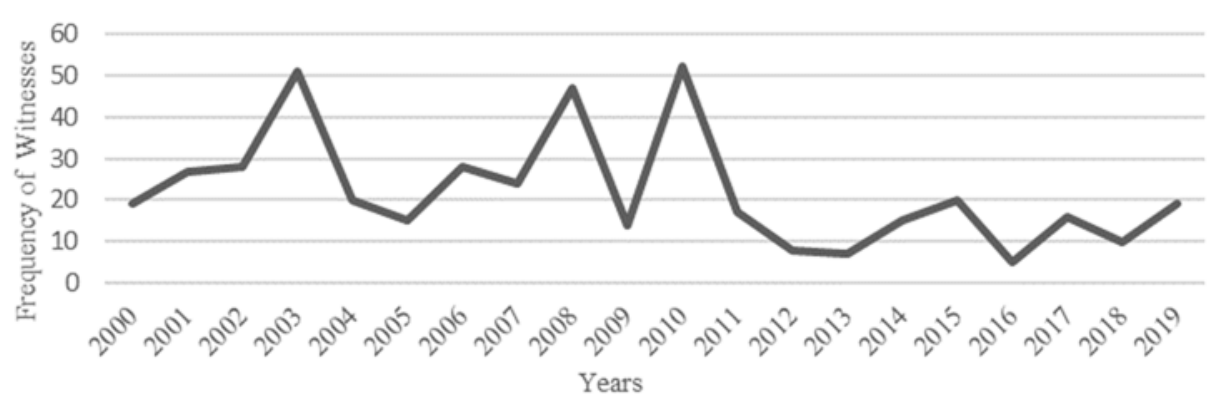

Figure 2: Congressional US Great Lakes Witnesses from 2000-2019 $(n=442)$. 
Based on these figures, it appears that there has been an ebb and flow of hearings ranging from a high of 14 hearings conducted in 2003, to a low of four hearings in both years 2000 and 2014. This indicates that Congress consistently conducts hearings on the Great Lakes with some variance in its attention per year. Likewise, the number of witnesses has a range from a high of 52 participants in 2010 to a low of only 5 witnesses in 2016. This range indicates that Congress appears to vary its attention and gathering of input from witnesses perhaps due to its priorities of other policies in a given year.

\subsection{The tone of hearings, committees and witnesses}

The measurement and analysis of several variables was conducted in order to provide a detailed examination of who has influence over congressional Great Lakes policymaking. The congressional chamber, committee and subcommittee conducting the hearings was noted. The hearing subject was included in the coding for the overall topic of the hearing. Topics focused on broad categories such as environmental protection, commerce and industry, transportation, natural disasters, and terrorism and border security. Hearings were also coded for being legislative if the purpose included a statute consideration. This is important because previous research has shown that congressional committees frequently use non-legislative hearings to expand their jurisdiction over time [6], [5]. Non-legislative hearings, which do not consider a piece of legislation for action, take the form of oversight, investigations or briefings on issues.

Often policy experts and affected parties serve as witnesses at these hearings. Individual witness tracking was employed in order to discern how often and under which committees and subcommittees the individual testified. For further analysis, witness organizational representation was then grouped into broad categories: federal agencies, state and local governments, trade associations, federal elected officials, academic researchers and institutions, think tanks and advocacy groups.

When examining congressional policymaking, one of the most important variables in the literature is the "tone" of the hearing, witness and committee. Past research has shown that while gathering information from witnesses, committees tend to only hear from participants reflecting a tone similar to the tone of the hearing or committee.

To investigate if this congruence of tone is occurring in Great Lakes policy during this time period, hearing, committee and subcommittee, and witness tone was identified and tracked over time. Tone is defined as being broadly environmentally protective of the Great Lakes ecosystem or supportive of its development for commerce, industry and transportation. If the tone was not discernible from the congressional documents, it was coded as neutral.

Changes in tone are particularly important indicators of policy changes and re-definition of the understanding of the Great Lakes. Tonal changes over time help to indicate the different eras of issue specific policymaking. Nonparametric statistical tests are used to test if there are significant changes in the tone and the relationship among the hearings, committee, and witnesses.

\section{RESULTS}

While many policy participants have a role in the management of the Great Lakes, the role of the committees of Congress, and their subcommittees, is essential. The work of congressional committees and their subcommittees of Congress take place in hearings with witness testimony. Hearing testimony includes gathering information from witnesses as well as the opinions and concerns of groups potentially affected by Great Lakes policies. 


\subsection{Congressional committee and hearings from 2000-2019}

A change from the past eras in terms of the committees and subcommittees conducting hearings on the Great Lakes occurred during Era IV. The US House of Representatives dominates with over $74 \%$ of the hearings being conducted in the chamber. Having more committees, it is not surprising that this chamber conducts more hearings than the US Senate. From 2000 to 2019, three of the total 20 committees involved with Great Lakes policymaking conducted 64\% of the hearings: Appropriations 37.4\%, Transportation and Infrastructure $16 \%$ and Environment and Public Works 10\%. The other 17 committees each held less than $10 \%$ of Great Lakes hearings, creating a fragmented approach to policymaking regarding a complex ecosystem. While the number of committees and subcommittees conducting hearings has not significantly changed from the past, the focus on appropriations is a departure. In both Era II and Era III congressional committees and their subcommittees were focused on issues of environmental concern for approximately a third of the hearings. Today, committees are focused on funding programs through the Subcommittees on Energy and Water Development (14\%), and Water Resources and the Environment (9.5\%), with the remaining 29 subcommittees conducting less than $7 \%$ of the hearings during this period. This indicates that Era IV is focused on funding programs that have been created in past congressional policymaking rather than generating completely new approaches or initiatives.

Research has shown that across eras, congressional committees tend to conduct hearings that are aligned with their policy agenda. Thus, the tone of the committee can be correlated with the tone of the hearing conducted (see Table 1).

Table 1: Tone of the committees and their hearings from 2000-2019 ( $n=147)$.

\begin{tabular}{|l|c|c|c|c|}
\hline \multirow{2}{*}{ Tone of the hearing } & \multicolumn{3}{|c|}{ Tone of committee } & Totals \\
\cline { 2 - 5 } & $\begin{array}{c}\text { Environmental } \\
\text { protection }\end{array}$ & $\begin{array}{c}\text { Commerce, } \\
\text { industry, } \\
\text { transportation }\end{array}$ & Neutral & Ton \\
\hline $\begin{array}{l}\text { Environmental } \\
\text { protection }\end{array}$ & $\begin{array}{c}86.4 \% \\
(19)\end{array}$ & $\begin{array}{c}9.1 \% \\
(2)\end{array}$ & $\begin{array}{c}4.5 \% \\
(1)\end{array}$ & $\begin{array}{c}100 \% \\
(22)\end{array}$ \\
\hline $\begin{array}{l}\text { Commerce, industry, } \\
\text { transportation }\end{array}$ & $\begin{array}{c}59.1 \% \\
(26)\end{array}$ & $\begin{array}{c}40.9 \% \\
(18)\end{array}$ & 0 & $\begin{array}{c}100 \% \\
(44)\end{array}$ \\
\hline Neutral & $\begin{array}{c}54.3 \% \\
(44)\end{array}$ & $\begin{array}{c}40.7 \% \\
(33)\end{array}$ & $\begin{array}{c}4.9 \% \\
(4)\end{array}$ & $\begin{array}{c}100 \% \\
(81)\end{array}$ \\
\hline Totals & $\begin{array}{c}60.5 \% \\
(89)\end{array}$ & $\begin{array}{c}36.1 \% \\
(53)\end{array}$ & $\begin{array}{c}3.4 \% \\
(5)\end{array}$ & $\begin{array}{c}100 \% \\
(147)\end{array}$ \\
\hline Kendall's Tau-b=.177 $(p=.018)$, Gamma $=.329(p=.018)$, Chi-Square=10.32 $(p=.035)$ \\
\hline
\end{tabular}

The results showed that there is a statistically significant and weak relationship of the tone of the committee reflecting the same tone as the hearing in Era IV (Kendall's Tau- $b=.177$, $p=.018$; Gamma $=.329, p=.018$; Chi-Square $=10.32 ; p=.035)$. The environmental protection tone of the committee frequently reflected the same tone of the hearing $(86.4 \%)$ more often than committees with a commerce, industry, and transportation tone $(40.9 \%)$. Era IV results demonstrate that congressional committees continue to use hearings to reinforce their policy positions and agenda for the Great Lakes. This poses a significant dilemma for the Great Lakes since congressional policymaking has not evolved into a sustainable development or 
collaborative approach towards management of the ecosystem. In fact, it may indicate that different programs in Congress have become entrenched in their jurisdictions rather than moving into a collaborative approach to lake management. It could also indicate a decline of the two major tones regarding the lakes and the potential for the evolution of a new tone or definition of the lakes. The strength of these nonparametric correlations is much weaker than in previous research which reported a strong relationship between the tone of the committee and the hearings they conduct. If this Era IV decline in correlation of tone between hearing and the committee continues into the future, it may be indicative of an erosion of committee jurisdictions.

\subsection{Witnesses who testify before Congress on the Great Lakes from 2000-2019}

Of the 443 witnesses who testified in hearing during Era IV, most were male $(84 \%)$ participating before non-legislative hearings (55\%). Previous research demonstrated of witness testimonies included 557 witnesses during Era II, and 858 witnesses in Era I. This indicates that while there is a continued reliance on male witnesses, there are significantly fewer witnesses participating than in past eras of hearings. Witnesses appear about $30 \%$ of the time before the House Transportation and Infrastructure Committee, with the House Appropriations Committee (18\%), and Senate Environmental and Public Works Committee $(13 \%)$ hearing from the next largest amounts of witnesses. Remaining committees attribute for less than $10 \%$ of witness testimony. This means witnesses are more likely to testify before committees that are interested in transportation and infrastructure issues than other issues associated with the Great Lakes.

Representatives of the executive branch of the federal government and its agencies represent the most frequent witnesses $(26.7 \%)$ with the U.S. Environmental Protection Agency being the largest repeat witness with 21 appearances. This is a large increase from the agency's previous years of participation indicating it has become a major participant in the hearings. The Great Lakes Indian Fish and Wildlife Commission, the Army Corp of Engineers, Fish and Wildlife, and the National Oceanic and Atmospheric Agency each range from 12-15 total repeat appearances before Congress. These are all federal agencies except for the Great Lakes Indian Fish and Wildlife which represents 11 Ojibwe tribes in Minnesota, Wisconsin, and Michigan who reserved hunting, fishing and gathering rights via treaties with the United States. Other witness categories that frequent the hearings include state and local governments (17\%), trade associations (13\%) and federal elected officials (11\%) from the surrounding Great Lakes states. In Era III, trade associations only comprised $8 \%$ of the witnesses. It appears that the federal government as well as the state and local governments remain major participants in congressional hearings, with similar levels of representation as Era III [18]. As in other policy areas, think tanks, academic researchers and institutions witnesses are not frequent participants. Instead, it appears that the specific users of the lakes tend to be represented [19]. There were no repeat appearances within or across committees that would classify a witness to being a hyper-expert in Great Lakes policymaking in Congress [18].

When analysis is performed using tone of the witnesses compared to tone of the hearing, it appears that hearings do not reflect a diversity of information, rather the tone of the witness reflects the tone of the hearing being conducted by the congressional committee (Table 2). This can indicate that committees are not receiving a wide range of information which may bring a different perspective to the topic of the hearing. There is a statistically moderate to strong relationship between the tone of the witness and the tone of the hearing they attend (Kendall's Tau- $\mathrm{b}=.438$, Gamma $=.778$, Chi-Square $=96.86, p<0.0001$ ). This is especially true 
for hearings being conducted with an environmental protection tone of the hearing $(90.3 \%)$ and similar, but to a lesser extent, with the tone of hearings and witnesses focused on commerce, industry and transportation (53.4\%). However, like the results of tone of the congressional committee and the hearings they conduct being weaker than in past eras of Great Lakes policymaking, these results reflect a weaker relationship compared to the previous eras.

Table 2: Tone of witness and hearing from 2000-2019 $(n=442)$.

\begin{tabular}{|l|c|c|c|c|}
\hline \multirow{2}{*}{ Tone of the hearing } & \multicolumn{3}{|c|}{ Tone of witness } & \\
\cline { 2 - 5 } & $\begin{array}{c}\text { Environmental } \\
\text { protection }\end{array}$ & $\begin{array}{c}\text { Commerce, } \\
\text { industry, } \\
\text { transportation }\end{array}$ & Neutral & Totals \\
\hline $\begin{array}{l}\text { Environmental } \\
\text { protection }\end{array}$ & $\begin{array}{c}90.3 \% \\
(298)\end{array}$ & $\begin{array}{c}9.4 \% \\
(31)\end{array}$ & $\begin{array}{c}.3 \% \\
(1)\end{array}$ & $\begin{array}{c}100 \% \\
(330)\end{array}$ \\
\hline $\begin{array}{l}\text { Commerce, industry, } \\
\text { transportation }\end{array}$ & $\begin{array}{c}45.6 \% \\
(47)\end{array}$ & $\begin{array}{c}53.4 \% \\
(55)\end{array}$ & $\begin{array}{c}1.0 \% \\
(1)\end{array}$ & $\begin{array}{c}100 \% \\
(103)\end{array}$ \\
\hline Neutral & $77.8 \%$ & $22.2 \%$ & 0 & $100 \%$ \\
& $(7)$ & $(2)$ & $19 \%$ \\
\hline Totals & $79.5 \%$ & $\begin{array}{c}19.9 \% \\
(88)\end{array}$ & $\begin{array}{c}.5 \% \\
(2)\end{array}$ \\
\hline \multicolumn{2}{|r|}{ Kendall's Tau-b=.438, Gamma $=.778$, Chi-Square $=96.86(p<0.0001)$} \\
\hline
\end{tabular}

\section{CONCLUSIONS}

It appears Great Lakes policymaking continues to reflect a bounded issue model where policy issues coexist but are not worked on across congressional committee jurisdictions. Like the previous eras, navigation, commerce, and industry share the agenda with environmental protection and human health. This appears to be a continuation of the agenda sharing set of issues that emerged in Era III.

After three eras of congressional policymaking, old problems persist, and some new ones are cropping up. Policymakers have determined that the Great Lakes are suffering from a set of disorganized programs [16], [20]. Since the opening of the St. Lawrence Seaway in 1959, ballast water has increasingly become the dominant pathway for non-native species to enter the Great Lakes. A variety of invasive species are a threat to the ecosystem of the lakes via ballast waters, and from the release of non-native species during flooding events [21], [22]. Non-native species continue to be a challenge for Great Lakes policymakers, particularly concerns about the Asian Carp [23]. This has been an ongoing threat to the lakes. The nonnative species permanently alter the ecosystem of the lakes usually through creating an imbalance in the food web.

The lakes continue to be plagued with legacy pollutants and emerging contaminants that pose environmental and public health concerns [24]. Legacy pollutants include heavy metals, polychlorinated bi-phenyls, dichlorodiphenyltrichloroethane, naphthalene, and dioxin [25]. While these chemicals were mostly banned or phased out decades ago, they have entered the Great Lakes ecosystem as the result of industrial accidents or spills, or through the disposal of hazardous materials, and persist in soil and aquatic sediments. They also bioaccumulate and bio-magnify, meaning that the concentration in animal tissues increases from bottom-dwelling microorganisms up the food web to increasingly larger fish and wildlife. Great Lakes fish monitoring studies indicate a considerable decline in legacy pollutant concentrations throughout the 1970s and 1980s. However, the decline began to slow 
around 1990, and mercury concentrations started to increase in recent years. In addition to well-known legacy pollutants, chemicals of emerging concern released to the Great Lakes ecosystem are being detected in water, sediments, fish, and wildlife [26]. Chemicals of emerging concern identified as threats to the Great Lakes watershed include per- and polyfluoroalkyl (PFAS), polybrominated diphenyl ethers (PBDEs) and current use pesticides [27]. PFASs have been produced and used in various industries and consumer products for over fifty years because of their water and oil repellence, thermal stability, and surfactant properties that make them extremely useful in industry. Since the first report on the worldwide contamination by PFASs, they have been detected in the human body, air, sediment, sludge, fish, and wildlife all over the globe, including high concentrations in Lake Ontario [28]. Per-fluoroalkane sulfonic acids (PFSAs) and perfluoroalkyl carboxylic acids (PFCAs) are two classes of PFASs that have been the focus of environmental research, monitoring, and regulatory efforts due to their occurrence, persistence and potential toxicity with significant concern about contaminated drinking water globally [29]. Several studies have shown that some PFASs can be classified as multisystem toxicants as well as developmental toxicants. PFOA and PFOS may be carcinogenic at relatively high doses, and repeated oral exposures may exert toxic effects [28]. In addition to legacy contaminants, nitrification and invasive species, these contaminants of emerging concerns are infiltrating the lakes and have poorly understood ecological and human health consequences [30].

Era IV reflects a focus on managing the lakes based on programs that were built as foundations from the previous eras with some exceptions like the emerging contaminants. The concern is what future policies are required for dealing with resiliency planning in preparation for climate change can take place in Congress [31]. For instance, water levels have always been a policy issue considered by Congress because they impact transportation and industry, as well as recreation and human health [32]. According to some modelling of climate change impacts on the lakes water resource managers need to prepare for the large interannual variability in lake levels, some of which have already been experienced in a nascent manner in the lakes [33]. Likewise, seasonal hypoxia and algal blooms in the lakes is not a new problem but can accelerate in occurrence based on climate change considerations creating widespread risks for the Great Lakes ecosystem [34]. Programs are well established to monitor and measure the Great Lakes with the awareness of climate change impacts [35]. The challenge to this acknowledged threat of climate change is that to plan for resiliency and coping with the changes that will occur to the lakes over time. This will require more cooperation and integration of congressional action than is currently taking place. It is anticipated that climate change impacts cannot be planned for or addressed with the bounded issue model where issues co-exist and rarely interact cooperatively. The International Joint Commission report stated that there is no Great Lakes basin-wide perspective, approach or strategy for addressing climate change [15]. The Commission recommends that there needs to be global leadership by jointly developing a binational approach to climate change adaptation and resilience in the Great Lakes. In 2018, the International Joint Commission issued guidance on how climate change could be addressed as a framework which should be also reflected in congressional policymaking [36].

Based on the past eras of policymaking in Congress in conjunction with this research that examines the last 20 years, planning for resiliency may be an important focus and re-definition for meeting the challenges into the future. Managing the Great Lakes in coordinating basin-wide goals and a monitoring system face several challenges from the lack of clearly defined organizational leadership and congressional policymaking [10]. One recommendation to strengthening the collaborative approach required for management of the lakes in the challenge of climate change is to improve committees' analytical capacities and 
using committees as independent sources of information on policy problems and solutions [37]. Great Lakes focused hearings conducted with joint committees that reflect a diversity of witnesses and interests is one solution. This approach could move congressional policymaking from the bounded issue model of past eras to a model with a more balanced tone reflecting the diversity of issues that can be negotiated and addressed with compromise. This approach may prove effective for the challenges of future resiliency planning.

\section{REFERENCES}

[1] Office of the Great Lakes National Parks, Facts and figures about the Great Lakes.

[2] Great Lakes Commission, About the Great Lakes.

[3] Gordon, S., The battles that shaped Great Lakes water politics. Wisconsin Public Radio and Wisconsin Public Television, 2018.

[4] Baumgartner, F., Jones, B.D. \& MacLeod, M.C., The evolution of legislative jurisdictions. Journal of Politics, 62, pp. 321-349, 2000.

[5] King, D.C., Turf Wars: How Congressional Committees Claim Jurisdiction, University of Chicago Press: Chicago, 1997.

[6] Jones, B.D., Baumgartner, F. \& Talbert, J.C., The destruction of issue monopolies in Congress. American Political Science Review, 87, pp. 657-671, 1993.

[7] Tzoumis, K., Environmental Policymaking in Congress: The Role of Issue Definitions in Wetlands, Great Lakes and Wildlife Policies, Routledge: New York, 2001.

[8] US Government Accountability Office, Great Lakes: Organizational leadership and restoration goals need to be better defined for monitoring restoration progress. Report to Congressional Requesters, 2004.

[9] Great Lakes Initiative: Epa needs to better ensure the complete and consistent implementation of water quality standards. Report to Congressional Requesters, Washington, DC, p. 53, 2005.

[10] US House of Representatives, Great Lakes initiative: Epa and states have made progress, but much remains to be done if water quality goals are to be achieved. Hearing before the Transportation and Infrastructure, 2008.

[11] Great Lakes Interagency Task Force, Great Lakes restoration initiative report to Congress and the President, 2017.

[12] Office of the Great Lakes National Parks, Great Lakes funding.

[13] EPA, Great Lakes water quality agreement, 2012.

[14] Great Lakes Water Institute and University of Wisconsin-Milwaukee, The Great Lakes compact, 2015.

[15] International Joint Commission, First triennial assessment of progress on Great Lakes water quality, 2017.

[16] Adler, T., The Great Lakes: Awash in policies. Environmental Health Perspectives, 113(3), pp. A174-A177, 2005.

[17] Proquest, Congressional research digital collection.

[18] May, P.J., Koski, C. \& Stramp, N., Issue expertise in policymaking. Journal of Public Policy, 36(2), pp. 195-218, 2016.

[19] Lerner, J.Y., Getting the message across: Evaluating think tank influence in Congress. Public Choice, 175(3-4), pp. 347-366, 2018.

[20] Jetoo, S., Barriers to effective eutrophication governance: A comparison of the Baltic Sea and North American Great Lakes. Water, 10(4), 2018.

[21] Sieracki, J.L., Bossenbroek, J.M. \& Chadderton, W.L., A spatial modeling approach to predicting the secondary spread of invasive species due to ballast water discharge. PLoS One, 9(12), e114217, 2014. 
[22] Phelps, Q.E., Tripp, S.J., Bales, K.R., James, D., Hrabik, R.A. \& Herzog, D.P., Incorporating basic and applied approaches to evaluate the effects of invasive Asian carp on native fishes: A necessary first step for integrated pest management. PLoS One, 12(9), e0184081, 2017.

[23] Asian Carp Regional Coordinating Committee, Asian carp action plan for fiscal year 2018, 2018.

[24] Burlakova, L.E., Karatayev, A.Y., Rudstam, L.G. \& Hinchey, E.K., U.S. Epa Great Lakes national program office monitoring of the Laurentian Great Lakes: Insights from 40 years of data collection. Journal of Great Lakes Research, 44, pp. 535-538, 2018.

[25] McGoldrick, D.J., Pelletier, M., de Solla, S.R., Marvin, C.H. \& Martin, P.A., Legacy of legacies: Chlorinated naphthalenes in Lake Trout, Walleye, herring gull eggs and sediments from the Laurentian Great Lakes indicate possible resuspension during contaminated sediment remediation. Science of The Total Environment, 634, pp. 14241434, 2018.

[26] Wattigney, W.A. et al., Biomonitoring programs in Michigan, Minnesota and New York to assess human exposure to Great Lakes contaminants. International Journal of Hygiene and Environmental Health, 222(1), pp. 125-135, 2019.

[27] International Joint Committee, Polybrominated Diphenyl Ethers (Pbdes) in the Great Lakes basin: Reducing risks to human health and the environment, 2016.

[28] Guo, R. et al., Application of a comprehensive extraction technique for the determination of poly- and perfluoroalkyl substances (Pfass) in Great Lakes Region sediments. Chemosphere, 164, pp. 535-546, 2016.

[29] Kaboré, H.A. et al., Worldwide drinking water occurrence and levels of newly identified perfluoroalkyl and polyfluoroalkyl substances. Science of The Total Environment, 616-617, pp. 1089-1100, 2018.

[30] Sunderland, E.M., Hu, X.C., Dassuncao, C., Tokranov, A.K., Wagner, C.C. \& Allen, J.G., A review of the pathways of human exposure to poly- and perfluoroalkyl substances (Pfass) and present understanding of health effects. Journal of Exposure Science \& Environmental Epidemiology, 29(2), pp. 131-147, 2019.

[31] Zou, B., Rockne, K.J., Vitousek, S. \& Noruzoliaee, M., Ecosystem and transportation infrastructure resilience in the Great Lakes. Environment: Science and Policy for Sustainable Development, 60(5), pp. 18-31, 2018.

[32] Gronewold, A.D., Fortin, V., Lofgren, B., Clites, A., Stow, C.A. \& Quinn, F., Coasts, water levels, and climate change: A Great Lakes perspective. Climatic Change, 120(4), pp. 697-711, 2013.

[33] Notaro, M., Bennington, V. \& Lofgren, B., Dynamical downscaling-based projections of Great Lakes water levels*+. Journal of Climate, 28(24), pp. 9721-9745, 2015.

[34] Tian, D. et al., Spatiotemporal variability and environmental factors of harmful algal blooms (habs) over Western Lake Erie. PLoS One, 12(6), e0179622, 2017.

[35] Environment and Climate Change Canada and the U.S. National Oceanic and Atmospheric Administration, 2018 annual climate trends and impacts summary for the Great Lakes Basin, 2019.

[36] International Joint Commission, Climate change guidance framework for Ijc boards. A highlights report, 2018.

[37] Lewallen, J., Theriault, S.M. \& Jones, B.D., Congressional dysfunction: An information processing perspective. Regulation \& Governance, 10(2), pp. 179-190, 2016. 